\title{
Nursing terminology as a work process instrument of nurses in collective health*
}

\author{
Terminologia de enfermagem como instrumento do processo \\ de trabalho do enfermeiro em saúde coletiva \\ Terminología de enfermería como instrumento del proceso \\ laboral del enfermero en salud colectiva
}

Marília Daniella Machado Araújo Cavalcante¹, Liliana Müller Larocca², Maria Marta Nolasco Chaves², Márcia Regina Cubas $^{3}$, Laura Christina Macedo Piosiadlo², Verônica de Azevedo Mazza ${ }^{2}$

How to cite this article:

Cavalcante MDMA, Larocca LM, Chaves MMN, Cubas MR, Piosiadlo LCM, Mazza VA. Nursing terminology as a work process instrument of nurses in collective health. Rev Esc Enferm USP. 2016;50(4):607-613. DOI: http://dx.doi.org/10.1590/S0080-623420160000500010

\footnotetext{
* Extracted from the dissertation "A Classificação Internacional para as Práticas de Enfermagem em Saúde Coletiva (CIPESC ${ }^{\circledR}$ ) como instrumento do processo de trabalho do enfermeiro em saúde coletiva”, Programa de Pós-Graduação em Enfermagem, Universidade Federal do Paraná, 2014

${ }^{1}$ Universidade Federal do Paraná, Departamento de Enfermagem, Programa de Pós-Graduação em Enfermagem, Curitiba, PR, Brazil.

${ }^{2}$ Universidade Federal do Paraná, Departamento de Enfermagem, Curitiba, PR, Brazil.

${ }^{3}$ Pontifícia Universidade Católica do Paraná, Programa de Pós-Graduação em Tecnologia em Saúde, Curitiba, PR, Brazil.
}

\section{ABTRACT}

Objective: To analyze the use of nursing terminology as an instrument of the nursing work process in Collective Health. Method: Exploratory case study. For data collection was conducted a group interview with 24 nurses working in health units of a municipality in south central Paraná, Brazil. Data were analyzed in the light of interdependence between the structural, particular and singular dimensions contained in the Theory of Nursing Praxis Intervention in Collective Health. Results: The situations interfering with improper use were the lack of knowledge about the origin and purpose of terminology, lack of training, and non-mandatory use. Conclusion: Although the nursing terminology is used as an instrument in the nursing work process in collective health, it requires training to be recognized as a classification system. At the same time, institutional policies should be employed to ensure the effective use of these instruments.

\section{DESCRIPTORS}

Community Health, Nursing; Primary Care Nursing; Nursing Process; Terminology; Classification. 


\section{INTRODUCTION}

The work process of nurses involves objects, agents, instruments, objectives, methods and products ${ }^{(1)}$. Nursing terminologies are instruments of the nursing work process, and defined as a set of terms describing the important concepts of the profession uniformly. Through these terminologies, it is possible to demonstrate the nursing contribution to health care ${ }^{(2)}$.

As members of the multidisciplinary team in Primary Health care, nurses have specific assignments. Thus, in the unique space of care provision, they need tools and methods that aim at the systematization of $\mathrm{care}^{(3)}$, and above all, are compatible with the assumptions of collective health.

When thinking about the work process in collective health, the use of critical and reflective thinking about the social determination of the health-disease process allows nurses to select more appropriate diagnoses and interventions to meet the recognized health needs and promote the transformation of vulnerabilities ${ }^{(4)}$.

The consolidation of Primary Care units as the gateway to the Unified Health System (SUS - Sistema Unico de Saúde) emphasized the need to use information technology to execution and documentation of nursing care and for planning health actions ${ }^{(5)}$. In addition to the care process, the development of a classification system for nursing practices stimulates changes and improves the quality of management, teaching and research, and enables the assessment of the nursing contribution to health care ${ }^{(6)}$.

The classification systems are fundamental to document the Nursing process ${ }^{(2)}$, which is defined as a methodological instrument that guides both the professional nursing care and the documentation of professional practice ${ }^{(7)}$. The International Council of Nurses (ICN) seeks the universalization of professional language for the agility and readiness to define diagnoses and interventions in nursing, and opportunities of dialogues at international level in different cultural, social and health contexts ${ }^{(8-9)}$.

The use of the vocabulary inventory derived from the International Classification of Nursing Practices in Collective Health (CIPESC ${ }^{\circledR}$ - Classificação Internacional para as Práticas de Enfermagem em Saúde Coletiva) as the work process tool in collective health guides the development of standards of diagnosis and care in nursing in Primary Care ${ }^{(8)}$. This inventory is the Brazilian contribution to the International Classification for Nursing Practice (ICNP $\left.{ }^{\circledR}\right)$, and one of the results of the project coordinated by the Brazilian Nursing Association developed in the late 1990s ${ }^{(3)}$.

The systematic application of the CIPESC ${ }^{\circledR}$ in Brazilian Primary Care as anchorage to name elements of nursing terminology stimulates the development of clinical and epidemiological reasoning, and can support the analysis of the health-disease process and the health needs of individuals, families and social groups. Thus, it proposes successful interventions, expanding the view of care in relation to users and the group to which they belong ${ }^{(8,10)}$.

Although its undeniable contribution to the discussion on the Brazilian nursing work process in the SUS, the review discussing the referenced production to nursing classifications in Brazil highlighted that the CIPESC ${ }^{\circledR}$ inventory was object of study in less than $10 \%$ of articles found in the databases available on the Virtual Health Library (VHL) (Biblioteca Virtual de Saúde - BVS). None of the articles focused on the care of nurses in collective health mentioned the CIPESC ${ }^{\circledR(11)}$.

The national scientific production is also clearly concentrated on experiences of using nursing classification systems focused on the hospital area ${ }^{(12)}$. Given this knowledge gap, the aim of this study was to analyze the use of the CIPESC ${ }^{\circledR}$ as an instrument of the nursing work process in collective health.

\section{METHOD}

This is an exploratory case study of qualitative approach. It was performed in a municipality located in the south central region of the state of Paraná. The population is 169,252 inhabitants, of which $91.43 \%$ live in the urban part of the municipality and only $62.81 \%$ of households have sewage network.

In the city, the illiteracy rate among people aged over 15 years is $6 \%$, ranking the $343^{\text {a }}$ position in the state. With regard to social vulnerability, in 2010, the municipality had $27.71 \%$ of people vulnerable to poverty, and $3.71 \%$ of extremely poor children. Furthermore, among the population aged 15-24 years, $10.09 \%$ do not study or work, and are vulnerable to poverty; $35.35 \%$ of the adult population has not completed primary school and have informal occupations; and $20.35 \%$ of mothers who are breadwinners (with children under 15 years) have not completed primary school ${ }^{(13)}$.

In 2011, the mortality rate of children under five years in the city was 22.24 deaths per 1,000 live births (ranking $83^{\text {rd }}$ in the state). The mortality rate of children under 1 year was 19.06 per 1,000 live births, occupying the $90^{\text {th }}$ position in the state rank. In that same year, the maternal mortality rate in the municipality was 35.30 per 100 thousand live births, considered better than the state average rate of 51.67 per 100,000 live births ${ }^{(13)}$.

As for Primary Care, the municipality has 33 health units distributed in five health districts. This corresponds to $64.89 \%$ of population coverage by teams of Community Health Agents, $65.23 \%$ of the population covered by teams of the Family Health Strategy, 32 accredited Oral Health teams, and two teams of support to Family Health implemented.

Each health unit has a nurse in the team. All these nurses constituted the universe of this study. The vocabulary inventory of CIPESC ${ }^{\circledR}$ is part of the computerized registration process of nursing care performed in the health units of this municipality.

The electronic medical records implemented in the municipality have a specific field to record the activities developed by nursing with space for describing the history of current complaint and physical examination; for selection of diagnoses and interventions using the CIPESC ${ }^{\circledR}$; and conclusion of assistance. The terminology used is restricted to the areas of health care of women and children, based on the material elaborated for the Municipal Secretariat of Health of Curitiba, capital of the state of Paraná ${ }^{(14)}$. 
The inclusion criteria were all individuals working in one of the Primary Health units of the municipality during the data collection period, which was between March and May 2014. The subjects on leave from work or on vacation during this period were excluded. The study participants were 24 nurses, mostly women, aged 20-40 years, experts with more than three years of graduation, and time working in public health services ranging from one to 20 years.

It was found that $70.8 \%$ (17) of nurses were admitted or assumed the teams after the implementation of the computerized system in the health units where they currently work. Regarding the vocabulary inventory of CIPESC ${ }^{\circledR}$, only four of them stated to know this instrument before its implementation in the municipality. Furthermore, 75\% (18) of nurses said they did not participate in the implementation process and only three reported their participation in the specific training to use the CIPESC ${ }^{\circledR}$.

Regarding training, the nurses reported it was provided only in the early years of the computerization of health units. Thus, many of the interviewed nurses had not participated of trainings because $37.5 \%$ (9) of them were summoned to take over their position in the last two years.

The group interview was conducted for data collection with five groups formed by different participants. The total number of groups was predefined considering the number of health districts as criteria. The meetings with the groups were held in the meeting room located on the reference health unit for each of the five districts. This was the place chosen by the participants for the interviews. Each group included four nurses on average, and the meetings lasted between 30 and 60 minutes.

The interviews were conducted by the researcher acting as moderator with the collaboration of an external observer to make records on the speeches and group dynamics. A questionnaire was developed to characterize the participants, as well as a thematic guide with questions regarding the nurses' knowledge about the vocabulary inventory of CIPESC ${ }^{\circledR}$, its deployment and implementation in the municipality and the health unit, and the use of CIPESC ${ }^{\circledR}$ in their work process.

The data collection strategy was the group interview. There was a dialogical stimulation among participants, which emphasized the development of collective skills in the use of $\mathrm{CIPESC}^{\circledR}$. The different adherence eventually presented by participants during the interview is considered a limitation of the strategy chosen.

The discussions during the group interview were audio recorded. The speeches were subsequently fully transcribed and subjected to content analysis in the thematic modality $^{(15)}$. To ensure privacy and anonymity, the speeches were presented by the identification of nurses (N1, N2, etc.), and the respective group according to chronological order ( $\mathrm{G} 1$, G2, G3, G4 and G5).

After organizing the empirical categories, the nurses' work process in collective health was analyzed in the light of the dimensional category of Interdependence between structural, particular and singular dimensions contained in the Theory of Nursing Praxis Intervention in Collective
Health (TIPESC - Teoria de Intervenção Práxica da Enfermagem em Saúde Coletiva) proposed by Egry ${ }^{(16)}$.

One of the premises of this reference proposes that the objective reality consists of three dimensions comprising the same whole and tightly connected to each other. Thus, depending on the phenomenon examined in the intervention, the singular dimension is what is the most specific and closest to the object, while the structural dimension is always the most distant from it, and the particular dimension is the mediation between the two mentioned dimensions ${ }^{(16)}$.

Therefore, in this article anchored in the TIPESC, the structural dimension is understood to be constituted by the health policy developed within the municipal health system. The particular dimension refers to the organization of services of the CIPESC ${ }^{\circledR}$, and the singular dimension refers to the logic used by nurses to use this classification system in their work. Note that this study gave emphasis to the presentation and discussion of the interdependence between the particular and singular dimensions.

The project was approved by the Research Ethics Committee accredited by the National Council for Ethics in Research (CONEP - Conselho Nacional de Ética em Pesquisa) under number 397.547, fulfilling all ethical precepts of Resolution 466/2012 of the National Health Council. All participants read and signed the Informed Consent form.

\section{RESULTS}

The Particular Dimension was composed of a subcategory called 'implementation of the computerized system in the municipality'. In the Singular Dimension emerged two subcategories, namely: 'the work process of nurses in collective health', and 'the CIPESC ${ }^{\circledR}$ as an instrument of the work process of nurses'.

\section{IMPLEMENTATION OF THE COMPUTERIZED SYSTEM IN THE MUNICIPALITY}

According to participants, the purpose of computerization was to incorporate the electronic medical record to unify the registration of users attended in all municipal health units, besides allowing a better registration and control of these consultations.

However, according to nurses, the vocabulary inventory of CIPESC ${ }^{\circledR}$ came simply as an additional item of the software purchased by the municipality. For them, the nursing leadership of the municipality had no prior intention of acquiring it (G3-N2).

(...) in fact, the CIPESC ${ }^{\circledR}$ was not implemented, the system was implemented. And the CIPESC ${ }^{\circledR}$ was inside this system. No emphasis was given at any time (G3-N2).

According to nurses, those responsible for the software attended a training at the time of implementation in the first healthcare units in order to train the team for the general use of the system. However, there was no specific training to use the $\mathrm{CIPESC}^{\circledR}(\mathrm{G} 1-\mathrm{N} 2)$.

(...) There was no specific training on the CIPESC ${ }^{\circledR}$. There was a training on the whole system, including this part (G1-N2). 
Thus, to use the electronic medical record and the CIPESC ${ }^{\circledR}$, nurses said they discovered the options in the system by themselves, or by exchanging information with colleagues who had already used the vocabulary inventory (G5-N3).

(...) we never had specific training. What I know I found out by myself or by calling the colleagues (G5-N3).

The nurses of the basic health network of the municipality did not participate in the computerized system deployment process. They recognize the influence of this fact in the use of instruments made available through it, such as the $\mathrm{CIPESC}{ }^{\circledR}$.

\section{The Work Process of nURSes in Primary Health CARe}

In the study setting, nurses of the health units are responsible for managing the service and assisting the registered population. According to participants, nurses are key elements for the implementation and effectiveness of actions and programs of health care defined in the three spheres of government.

The work process of nurses in Primary Health care is recognized and emphasized by participants as overworked because most activities of the health units are directed to them (G3-N4).

(...) it is really a problem we all have, because the administrative part is very demanding, the same way as the assistance is also demanding. Besides, with all the programs; there are many programs. So we're really overworked (G3-N4).

\section{The CIPESC ${ }^{\circledR}$ AS AN INSTRUMENT OF THE WORK PROCESS OF NURSES}

Participants had no knowledge about the vocabulary inventory of CIPESC ${ }^{\circledR}$ before the implementation of the computerized system in the municipality. Furthermore, the fact of terminology usage not being mandatory in nursing consultations also favored the use of the instrument conditioned to the nurses' curiosity (G3-N1).

(...) Here, everybody who used it did it more out of curiosity. At no time, we were requested to use it as a routine, incorporate it in actual consultations in order to make assessments later (G3-N1).

When asked if nurses perceived differences in the work process by using the classification system in the nursing consultation, their statements were contradictory. Despite considering the use of CIPESC ${ }^{\circledR}$ easy, they admitted not using it for lack of habit and work overload (G2-N3).

(...) It is very easy to use. I guess I end up not using it for being in a burry, for lack of habit (G2-N3).

The nurses who reported noticing difference in the work process mentioned the legal support and visibility of actions developed by nurses as the potentialities of using the vocabulary inventory. For nurses, the CIPESC ${ }^{\circledR}$ is useful to remember the interventions and guidelines that should be provided to users, and it shows the nursing evolution with better monitoring of the clinical condition. Nurses also reported the practicality of using the CIPESC ${ }^{\circledR}$ integrated with the computerized system in nursing consultations, and in the choice of nursing diagnosis and interventions.

However, participants pointed as a weakness of the CIPESC ${ }^{\circledR}$ available in the computerized system of the municipality, the coverage of diagnoses and nursing interventions related only to the areas of women's health and child health. They recognized the need to include terms related to other areas, such as health of the elderly, men's health, prenatal care, diabetic and hypertensive patients.

Nurses have pointed as a limitation of the CIPESC ${ }^{\circledR}$, the fact that the software purchased by the municipality allows the selection of only two diagnoses for each user. They also classified the nursing interventions as bearing little compatibility with the socioeconomic situation of users. In addition, the fact that it is not possible to modify or rewrite new interventions from the reality of users, compromises the use of CIPESC ${ }^{\circledR}$ during nursing consultations (G3-N4).

(...) the available options are limiting too, since you cannot describe the reality or, for example, the situation of that pregnant woman because it is not satisfactory. It should be a little more open or have more options (G3-N4).

Finally, nurses have perceived incoherence between the nursing diagnoses and the respective available interventions, and indicated it as a factor that hinders the use of CIPESC ${ }^{\circledR}$.

\section{DISCUSSION}

Discussions about the performance of health professionals in the SUS converge to the recognition that nurses are mediators and the main dynamic agent of policies and programs focused on collective health ${ }^{(17)}$. The current organization of the Primary Care policy of SUS defines a remarkable field of action for nurses, especially the management, care and educational skills taken by these professionals ${ }^{(18)}$.

This complexity of actions may be an explanation for municipalities as that of the present study using professional nurses working in health units as managers of service and care. At the same time, the ministerial protocols of Brazilian Primary Care for nurses, include the activities of direct care to individuals, families and community. Thus, the accumulation of administrative and assistance tasks reported by nurses in Primary Care units reflects unfavorable conditions for the potential use of the CIPESC ${ }^{\circledR}$ inventory in nursing consultation in everyday services.

The Federal Board of Nursing has legislated on the skills of nursing professionals and about the notes that must be documented. Among them, there is Resolution number 358/2009, which considers the Systematization of Nursing Care and Nursing consultations as methods of the work process that show the contribution of nurses to the health care of population, increasing the visibility and professional recognition $^{(7)}$.

In response to this legal settlement, some services deploy systems for documentation of care without discussing their suitability to the reality of the local work process. The contradiction identified in the implementation of CIPESC ${ }^{\circledR}$ in the study scenario was the fact that the 
local management provided a software with a work instrument for exclusive use of nurses without the participation of these professionals.

Note that the effective acceptance of the incorporation of new technologies depends on the involvement of end users since the beginning of the process, with active participation in subsequent stages ${ }^{(19)}$. Thus, the speeches of participants showed that not participating in the software implementation process reflected in the critical and reflective use of the instrument.

The nursing consultation focused on problem situations and the health needs of users allows nurses to use clinical reasoning and determine diagnosis and nursing interventions by bringing more scientificity to this set of actions, which consequently accredits the professional before the multidisciplinary team and users ${ }^{(5)}$.

Regarding the use of nursing terminologies in the context of public health, a study on the use of the Omaha System demonstrated its potential to serve as a common language for the assessment of community, and as a promising strategy for the international electronic exchange of health data of the population ${ }^{(20)}$.

The Omaha system can generate reliable and valid data at multiple levels, resulting in potential to expand the evidence of efficacy of public health nursing and therefore, improvement of the population's health. Thus, the use of terminologies can promote the practice of evidence-based nursing in public health ${ }^{(20)}$.

Thus, there is the need to use a language based on standardized terminologies, such as the vocabulary inventory of CIPESC ${ }^{\circledR}$ in order to ensure proper medical records of data obtained during nursing consultations. Hence, there is a better communication of the performance of nursing, facilitating the conduction of studies on the care and comparison between the best nursing practices ${ }^{(2)}$.

However, in the study setting, was observed propensity to disinterest on the routine application of CIPESC ${ }^{\circledR}$ in nursing consultations. Participants showed weakness in using this instrument and a tendency to disoblige themselves from a practice based on clinical reasoning and critical and reflective thinking, with little understanding of the context of elaboration and complexity of CIPESC ${ }^{\circledR}$, as well as its applicability as a nursing classification system.

On the other hand, participants who showed proximity to the vocabulary inventory criticized the software and CIPESC ${ }^{\circledR}$, because they perceived more clearly the gap of the available terminology, its limitations and the need for upgrades. Note that the terminology implemented in the study scenario municipality has changed since its creation in 2000. The updates have not been incorporated in the software by the responsible company and, therefore, were not available to nurses in this study.

Nurses of Primary Care, along with their managers and in partnership with educational institutions should promote discussions in order to bring the CIPESC ${ }^{\circledR}$ to the reality of the health needs of the municipality population.

The interconnection of classification systems such as the CIPESC ${ }^{\circledR}$ with computer systems facilitates the identification of nursing interventions that will be performed according to the diagnosis made. However, by incorporating software programs to the nursing practice, it is essential that nurses have knowledge and ability to manipulate the classifications, and clinical reasoning to elaborate diagnoses and nursing prescriptions ${ }^{(19)}$.

There was as contradictory process in the speeches of participants. The nurses recognized that CIPESC ${ }^{\circledR}$ is practical and can be a useful assessment instrument, and at the same time admitted not using it because of accumulation of tasks, work overload and lack of habit.

The ignorance of the origin and purpose of CIPESC ${ }^{\circledR}$, lack of training, non-mandatory use, and unfavorable working conditions were found as contradictory processes in the three dimensions. They contribute to nurses' neglect of the application of the vocabulary inventory as an instrument of the work process in collective health available in the computerized system.

The existence of a system favoring the implementation of the stages of strategic planning (SP) is not sufficient. In practice, it is also essential that nurses develop new skills, trying to employ their clinical reasoning through a complete evaluation in order to meet the health needs presented by individuals, family and the community ${ }^{(19)}$.

There is a concerning fact related to the nurses' reports on the knowledge acquired about the CIPESC ${ }^{\circledR}$. The informal search for information and disconnected from scientific anchoring is incompatible with the need for scientificity of the profession. Therefore, the finding that a professional of superior level, an expert, searches for knowledge informally is contradictory to one of the purposes of using a systematic language, which is to provide evidence to the care process.

The significant involvement with evidence-based practice requires that nurses have the skills to do more than simply ask their colleagues for information when faced with a problem in practice. There are international studies showing the lack of knowledge about research and the discomfort to understand its terminologies as the main reasons why nurses do not use evidence in practice ${ }^{(21)}$.

Contradictions in the reality of public health trigger transformations, and the practices in this field take place in their explicitness and in interventions to overcome them. Therefore, the public health nursing should be trained to use methods capable of intervening in reality, and based on theoretical and philosophical principles of collective health ${ }^{(4)}$.

A systematic review studied the effectiveness of interventions to improve the literacy of nurses in research. It found that interactive or activity-based learning, and the use of an adequate theory are processes that contribute to the improvement of knowledge about investigation, of the critical reflection capacity, and self-efficacy in research. Thus, this seems a clear choice for inclusion by the educational system in order to promote the use of evidence-based practice by nurses ${ }^{(21)}$.

As an overcoming alternative, $\mathrm{CIPESC}^{\circledR}$ is a powerful pedagogical instrument for the training and qualification of 
Brazilian nurses committed to the development of $\operatorname{SUS}^{(8)}$. Accordingly, it is essential to approach CIPESC ${ }^{\circledR}$ and the professional training during the academic core, since the main challenge is to overcome the use of a classification system as a mere instrument of work and see it as a technological innovation capable of producing changes that give opportunity for the Nursing work ${ }^{(22)}$.

\section{CONCLUSION}

In the interpretation of objective reality it was possible to identify the limited knowledge of nurses about the CIPESC $^{\circledR}$. Although it is available on the computerized system of the municipality, CIPESC ${ }^{\circledR}$ is used by nurses mechanically, as a mere additional software item.

In relation to weaknesses, the contradiction of nurses' statements stands out. On the one hand, they mention the importance of using the CIPESC ${ }^{\circledR}$ inventory during nursing consultations and, on the other hand, they admit not using it for lack of habit and work overload, with especial emphasis on administrative activities.

There is a similar contradiction in the mentioned potentialities because at the same time that nurses recognize the benefits of using $\mathrm{CIPESC}^{\circledR}$, they do not include it in their work process systematically.
In relation to overcoming these contradictions, note that the implementation of systematization of nursing care (SNC), and a classification system involves institutional and individual behavior changes. To that end, strategies promoting the incorporation of this methodology in practice need to be thought and discussed in three dimensions: of nurses, the collective of these professionals, and of the local manager.

Although there are universal terms, the terminologies should be adapted to local realities to be recognized by professionals who will use them, provide diagnoses, interventions and appropriate nursing outcomes to the health needs of the assisted population.

Such aspects demonstrate the need for a more significant approach to nursing classification systems in educational institutions, contributing to use this work instrument with efficiency, efficacy and effectiveness in order to ensure improved quality of assistance provided to the community and reaffirmation of professional autonomy.

Although the study presents limitations because the reality has been objectified by the different adherence of participants to the group interview, the scientific findings presented may contribute to nurses rethink the strategies for using nursing terminologies as an instrument of their work process in collective health.

\section{RESUMO}

Objetivo: Analisar a utilização de terminologia de enfermagem como instrumento do processo de trabalho do enfermeiro em Saúde Coletiva. Método: Estudo de caso exploratório. Para coleta de dados foi realizada entrevista em grupo com 24 enfermeiros que atuam nas unidades de saúde de um município no centro-sul do Paraná, Brasil. Os dados foram analisados à luz da interdependência entre as dimensões estrutural, particular e singular contidas na Teoria da Intervenção Práxica de Enfermagem em Saúde Coletiva. Resultados: As situações que interferiram na utilização inadequada foram o desconhecimento sobre origem e finalidade da terminologia, a falta de treinamento e a não obrigatoriedade de uso. Conclusão: A terminologia de enfermagem, apesar de utilizada como instrumento no processo de trabalho de enfermeiros em Saúde Coletiva, necessita de capacitação para ser reconhecida como sistema classificatório. Ao mesmo tempo, políticas institucionais devem ser empregadas no intuito de garantir a efetiva utilização destes instrumentos.

\section{DESCRITORES}

Enfermagem em Saúde Comunitária; Enfermagem de Atenção Primária; Processos de Enfermagem; Terminologia; Classificação.

\section{RESUMEN}

Objetivo: Analizar la utilización de terminología de enfermería como instrumento del proceso laboral del enfermero en Salud Colectiva. Método: Estudio de caso exploratorio. Para la recolección de datos fue realizada entrevista en grupo con 24 enfermeros que actúan en los centros de salud de un municipio del centro-sur de Paraná, Brasil. Los datos fueron analizados a la luz de la interdependencia entre las dimensiones estructural, privada y singular abarcadas en la Teoría de la Intervención Práctica de la Enfermería en Salud Colectiva. Resultados: Las situaciones que interfirieron en el empleo inadecuado fueron el desconocimiento acerca del origen y finalidad de la terminología, la falta de entrenamiento y la no obligatoriedad de uso. Conclusión: La terminología de enfermería, a pesar de utilizada como instrumento en el proceso laboral de enfermeros en Salud Colectiva, necesita capacitación para ser reconocida como sistema clasificatorio. Además, se deben emplear políticas institucionales a fin de asegurar la efectiva utilización de esos instrumentos.

\section{DESCRIPTORES}

Enfermería en Salud Comunitaria; Enfermería de Atención Primaria; Procesos de Enfermería; Terminología; Clasificación.

\section{REFERENCES}

1. Sanna MC. Os processos de trabalho em Enfermagem. Rev Bras Enferm. 2007;60(2):221-4.

2. Barra DCC, Sasso GTMD. Padrões de dados, terminologias e sistemas de classificação para o cuidado em saúde e enfermagem. Rev Bras Enferm. 2011;64(6):1141-9.

3. Cubas MR, Albuquerque LM, Martins SK, Peruzzo SA. Aplicação do Inventario Vocabular Resultante do Projeto CIPESC CIE-ABEn nas Unidades Básicas de Saúde do Município de Curitiba-PR. 2010. In: Egry EY, Garcia TR. Integralidade da atenção no SUS e sistematização da assistência de enfermagem. Porto Alegre: Artmed; 2010. p. 318-23. 
4. Chaves MMN, Larocca LM, Peres AM. Collective Health Nursing: the construction of critical thinking about the reality of health. Rev Esc Enferm USP [Internet]. 2011 [cited 2015 Nov 19];45(n.spe2):1701-4. Available from: http://www.scielo.br/pdf/reeusp/v45nspe2/en_11.pdf

5. Silva SH, Cubas MR, Fedalto MA, Silva SR, Lima TCC. Evaluative study of nursing consultation in the basic networks of Curitiba, Brazil. Rev Esc Enferm USP [Internet]. 2010 [cited 2015 Nov 19];44(1):67-74. Available from: http://www.scielo.br/pdf/reeusp/v44n1/en_a10v44n1.pdf

6. Cubas MR, Silva SH, Rosso M. Classificação Internacional para a Prática de Enfermagem (CIPE®): uma revisão de literatura. Rev Eletr Enf [Internet]. 2010 [citado 2015 nov. 19]12(1):186-94. Disponível em: http://www.fen.ufg.br/revista/v12/n1/v12n1a23.htm.

7. Conselho Federal de Enfermagem. Resolução COFEN n. 358, 15 de outubro de 2009. Dispõe sobre a Sistematização da Assistência de Enfermagem e a implementação do Processo de Enfermagem em ambientes, públicos ou privados, em que ocorre o cuidado profissional de Enfermagem, e dá outras providências [Internet]. Brasília: COFEN; 2009 [citado 2015 nov. 19]. Disponível em: http://www.cofen.gov. br/resoluo-cofen-3582009_4384.html

8. Nichiata LYI, Padoveze MC, Ciosak SI, Gryschek ALFPL, Costa AA, Takahashi RF, et al. The International Classification of Public Health Nursing Practices - CIPESCR: a pedagogical tool for epidemiological studies. Rev Esc Enferm USP [Internet]. 2012 [cited 2015 Nov 19];46(3):759-64. Available from: http://www.scielo.br/pdf/reeusp/v46n3/en_32.pdf

9. Furuya RK, Nakamura FRY, Gastaldi AB, Rossi LA. Sistemas de classificação de Enfermagem e sua aplicação na assistência: revisão integrativa de literatura. Rev Gaúcha Enferm. 2011;32(1):167-75.

10. Alves KYA, Dantas CN, Salvador PTCdO, Dantas RAN. Vivenciando a classificação internacional de práticas de enfermagem em saúde coletiva: relato de experiência. Esc Anna Nery Rev Enferm. 2013;17(2):381-8.

11. Cubas MR, Egry EY. Classificação Internacional de Práticas de Enfermagem em Saúde Coletiva - CIPESC®. Rev Esc Enferm USP. 2008;42(1):181-6.

12. Cavalcante RB, Otoni A, Bernardes MFVG, Cunha SGS, Santos CS, Silva PC. Experiências de sistematização da assistência de Enfermagem no Brasil: um estudo bibliográfico. Rev Enferm UFSM. 2011;1(3):461-71.

13. Instituto de Pesquisa Econômica e Aplicada. Atlas do desenvolvimento humano no Brasil, 2013 [Internet]. Brasília; 2013 [citado 2015 nov. 19]. Disponível em: http://www.atlasbrasil.org.br/2013/pt/

14. Cubas MR, Albuquerque LM, Martins SK, Nóbrega MML. Avaliação da implantação da CIPESC em Curitiba. Rev Esc Enferm USP. 2006;40(2):269-73.

15. Minayo MCdS. O desafio do conhecimento: pesquisa qualitativa em saúde. 13a ed. São Paulo: Hucitec; 2013.

16. Egry EY. Saúde coletiva: construindo um novo método em Enfermagem. São Paulo: Ícone; 1996.

17. Backes DS, Backes MS, Erdmann AL, Büscher A. O papel profissional do enfermeiro no Sistema Único de Saúde: da saúde comunitária à estratégia de saúde da família. Ciênc Saúde Coletiva. 2012;17(1):223-30.

18. Pires MRGM. The limitations and possibilities of nurses' work in the family health strategy: in the search for autonomy. Rev Esc Enferm USP [Internet]. 2011 [cited 2015;45(n.spe2):1710-5. Available from: http://www.scielo.br/pdf/reeusp/v45nspe2/en_13.pdf

19. Carvalho CMG, Moro CMC, Cubas MR, Malucelli A. Sistemas de Informação em Saúde que integram terminologias de Enfermagem: uma revisão de literatura. J Health Inform. 2012;4(2):50-4.

20. Kerr MJ, Flaten C, Honey ML, Gargantua-Aguila SD, Nahcivan NO, Martin KS, et al. Feasibility of using the Omaha System for communitylevel observations. Public Health Nurs. 2016;33(3):256-63.

21. Hines S, Ramsbotham J, Coyer F. The effectiveness of interventions for improving the research literacy of nurses: a systematic review. Worldviews Evid Based Nurs. 2015;12(5):265-72.

22. Cubas MR. Instrumentos de inovação tecnológica e política no trabalho em saúde e em enfermagem: a experiência da CIPE ${ }^{\circledR} / C_{P}$ ESC ${ }^{\circledR}$. Rev Bras Enferm. 2009;62(5):745-7. 